\title{
A STUDY OF PHOSPHORUS ABSORPTION IN NORMAL AND RACHITIC CHILDREN.
}

\author{
BY \\ $\checkmark$ GEORGINA MURDOCH, M.B., Ch.B.
}

(From the Medical Department, Royal Hospital for Sick Children, Glasgow.)

The disordered metabolism of the inorganic constituents of bone in the rachitic child has long been the subject of research, in the course of which a mass of valuable experimental data has accumulated. Nevertheless, it must be admitted that in rickets the causa causans remains obscure, and further, that with regard to the interpretation of much of the experimental evidence in our possession, there is no unanimity of opinion. Thus, it is still an undecided point whether the fundamental error lies in the assimilation of phosphorus or in that of calcium, the issue being confused by the intimate reciprocal relation which exists between these elements in every phase of their metabolism.

One of the most constant findings in rickets is a reduction in the inorganic phosphorus content of the blood, a point first noted by Iversen and Lenstrup ( ${ }^{1}$ ) and shortly afterwards confirmed by Howland and Kramer $\left({ }^{2}\right)$. On the other hand, the blood calcium, at least in uncomplicated rickets in the human subject, is not far removed from the normal $\left({ }^{3}\right)$. A consideration of these facts, together with the results of metabolism experiments on rachitic as compared with normal children, led Howland $\left({ }^{4}\right)$ to conclude that the essential defect in rickets consists in an impaired absorption of phosphorus. Other American investigators, notably Hess and his collaborators $\left({ }^{5}\right)\left({ }^{6}\right)$ have laid similar stress on the question of phosphorus metabolism in relation to rickets.

These views are not, however, shared by the Glasgow School. In 1924 Findlay $\left(^{7}\right)$ stated that in his judgement the intrinsic disturbance was one of calcium metabolism, and while admitting that the possibility of a defective fixation of calcium by the growing cartilage had not definitely been excluded, he was inclined to the idea that the failure of calcification in rickets is the result of interference with the normal absorption of lime salts from the gut. The experimental studies of Telfer $\left(^{8}\right)$ on normal and rachitic infants led him also to the conclusion that in the latter the role of defective calcium assimilation was of the first importance.

A survey of the facts, so far as they are at present known, with regard to calcium and phosphorus metabolism in health and in rickets, will serve to indicate the grounds upon which these divergent opinions are based.

In most foodstuffs calcium and phosphorus occur chiefly in inorganic form, though also to a lesser extent in organic combination. It is in the 
former that they are for the most part absorbed. Solution of the greater part of the compounds ingested is brought about by the acid gastric juice, and absorption then proceeds until, passing into the intestine, the chyme becomes alkalinized, and the calcium remaining unabsorbed is thrown out in the form of the insoluble tertiary phosphate of lime. Further free absorption cannot then take place. Apparently, therefore, even under normal conditions, absorption of calcium is limited to a fraction of the intake, and occurs, for the most part, over a very restricted area. Moreover, it is largely influenced by the $p \mathbf{H}$ of the secretions in this area, and may be seriously interfered with by any increase in the latter. Telfer's work $\left(^{8}\right)$ on the normal metabolism of calcium in children and in animals goes far to confute the theory, long held, that calcium is absorbed in excess of requirements and to a large extent re-excreted into the intestine. On the contrary, it points definitely to the fact that " the greater part of the calcium intake is restricted to the gut, and except the small amount excreted in the urine, the amount absorbed is nearly equivalent to the amount retained." The same experimental study showed the significance of the urinary calcium as an approximate measure of the absorption of this substance. Increase in the calcium intake was followed by improved retention accompanied by a slight rise in the urinary calcium, while a diminished intake resulted in a corresponding fall. Ahlquist's investigations $\left({ }^{9}\right)$ of the metabolism of lime in normal children also demonstrated the importance of this point.

In contrast to calcium, phosphorus is freely absorbed from the alimentary tract. Its inorganic salts are dissolved by the gastric juice, and the bulk of the ingested phosphorus is probably absorbed in this form ${ }^{8}$ ). During intestinal digestion organic phosphorus compounds are split up, and the phosphoric acid thus set free is further rendered available for absorption.

Normally, phosphorus is found in considerable quantity in both urine and fæces. The fæcal phosphorus has been shown to be simply the unabsorbable mineral residue of the food. Locked up in insoluble combination with calcium, it has passed through the body without taking any part in metabolism beyond the intestinal wall. Excess of phosphorus over the amount required for the conversion of calcium in the intestine into $\mathrm{Ca}_{3}\left(\mathrm{PO}_{4}\right)_{2}$ is absorbed, and in so far as it is not required for growth and repair of tissue, is eliminated in the urine.

Under normal conditions, the percentage of phosphorus absorbed depends mainly upon the extent to which precipitation of $\mathrm{Ca}_{3}\left(\mathrm{PO}_{4}\right)_{2}$ takes place. Any factor, for example, excess of lime in the food, which leads to increased formation of this salt, will restrict a larger amount of phosphorus to the intestine, leaving relatively less to be excreted by the kidneys, while the opposite effect will be produced by factors causing a reduced formation of $\mathrm{Ca}_{3}\left(\mathrm{PO}_{4}\right)_{2}$. Thus it has been shown by Hoobler $\left({ }^{10}\right)$ and confirmed by Telfer $\left(^{8}\right)$ that an excess of fatty derivatives in the intestine results in the elimination of increased quantities of calcium in the form of insoluble soaps, so that relatively less phosphorus is calcium-bound, and more is free to be absorbed. 
These facts have an important bearing upon the deranged metabolism of the elements in question in rickets. In the active stage of this disease, as the early experiments of Schabad (11) proved, and those of other observers have since confirmed, there is a greatly diminished retention of calcium and phosphorus, more especially of the latter, and abnormally large quantities of both are excreted in the fæces. In the urine calcium is reduced to an insignificant fraction, while the amount of phosphorus, though little changed absolutely, constitutes a much smaller proportion of the total excretion than in health. On the other hand, the healing stage of rickets is characterized by an abnormally high positive calcium-phosphorus balance, and a reduction in the elimination of these by way of the intestine. The quantity of phosphorus in the urine remains practically the same, so that the improved retention occurs at the expense of that which had previously been excreted in the fæces. The change in the partition of calcium between urine and fæces is less striking, but Orr and others $\left({ }^{12}\right)$ demonstrated that in a number of cases an increased percentage was excreted in the urine, and that this was due quite as much to actual increase in the quantity of calcium found in the urine, as to the diminution of this element in the fæces. Wills, Sanderson and Paterson $\left({ }^{13}\right)$ have also recorded an increase in the urinary calcium during the healing stage of rickets.

If 'Telfer's hypothesis be accepted, that under normal physiological conditions the calcium content of the fæces represents not an excretion from the blood, but merely the unabsorbed portion of the intake, then the importance of its application in the case of rickets becomes manifest. In the absence of proof that in this disease an abnormal mode of excretion exists (and as Findlay $\left({ }^{7}\right)$ has pointed out, indisputable evidence to this effect is lacking) it follows that the surplus of calcium in the fæces in rickets is the result, not as had been generally assumed, of increased excretion into, but of diminished absorption of lime from the gut. The influence of an excess of calcium upon the absorption of phosphorus is well known, and has already been mentioned. Whether such an excess be due to increased intake, or to defective absorption of calcium, the effect will equally be to restrict an increased amount of phosphorus to the intestine. It follows that the abnormal excretion of phosphorus in the fæces in rickets may be entirely secondary to the error in calcium metabolism, and is not necessarily to be taken as evidence of an impaired power of absorbing phosphorus as such.

The results of certain metabolism experiments carried out by Findlay and Telfer $\left(^{7}\right)$ lend strong support to this view. In two cases of late rickets the diet was adjusted so that it contained a minimal quantity ( $0.16 \mathrm{grm}$.) of $\mathrm{CaO}$ per day, and the excretion of calcium and phosphorus was followed. It was found that of the total amount of phosphorus eliminated, 74 per cent. occurred in the urine. Increase in the daily intake of $\mathrm{CaO}$ by the addition of calcium lactate to the diet brought about a striking change, in that the urinary phosphorus was much reduced, in one case to almost half the previous amount. It was thus shown that in these cases absorption of phosphorus was actually unimpaired, though the fact emerged clearly only when the deterrent influence 
of calcium was as far as possible removed, a point to which attention was directed for the first time.

In view of these observations it became important to determine whether the concentration of phosphorus in the serum is influenced in like manner by variations in the calcium and phosphorus intake, and in particular, whether any significant difference can be demonstrated between such response in the rachitic and the normal child. It was with this object in view that the present investigation was undertaken.

The work was divided into two parts. In the first, the level of the inorganic phosphorus of the serum in normal and rachitic children was followed throughout a period of several weeks, during which alterations were made from time to time in the intake of calcium and phosphorus. In the second, the absorption of phosphorus in rickets was compared with that in health by tracing the rise in the serum phosphate in both, following the administration by mouth of a single dose of acid sodium phosphate.

\section{Part I. Study of Serum Phosphorus.}

Method.

The first group selected for study consisted of three children, from $1 \frac{1}{4}$ to $1 \frac{2}{3}$ years of age who suffered from rickets in the active stage as evidenced by radiograms; the second, of nine non-rachitic children varying in age from 5 months to 10 years. Of the latter, hereinafter briefly designated " normal," one had recovered from chorea, two from bronchitis, and the remainder suffered from chronic rheumatic carditis, conditions presumably unaccompanied by any error in calcium or phosphorus metabolism.

A basic diet low in calcium was chosen. The older children (8-10 years) received the following daily allowance :-

Diet $A$. Meat 100 grm., potato 120 grm., bread 200 grm., banana 50 grm., butter and honey of each 25 grm., orange juice 50 c.c., and cocoa 6 grm. This contains, according to a calculation from tables supplied by Sherman $\left({ }^{14}\right)$, approximately $0 \cdot 16 \mathrm{grm}$. CaO, and $1 \cdot 16 \mathrm{grm}$. $\mathrm{P}_{2} \mathrm{O}_{5}$. It was impossible to reduce the calcium intake to a comparable extent in the case of the younger children (under 2 years) whose diet necessarily contained a considerable quantity of milk. Two of these received daily $0.79 \mathrm{grm}$. $\mathrm{CaO}$ and $\mathrm{l} \cdot 1 \mathrm{grm} . \mathrm{P}_{2} \mathrm{O}_{5}$ in the following diet :-

Diet $B$. Milk, 450 c.c. diluted with water 600 c.c., 40 per cent. cream 30 c.c., sugar 62 grm., bread 30 grm., and butter $4 \mathrm{grm}$. In the remaining two cases, a normal child of 5 months, and a rachitic of $1 \frac{1}{2}$ years, the diet consisted of whole milk, no attempt being made to reduce the calcium intake.

Changes in the intake of $\mathrm{CaO}$ and $\mathrm{P}_{2} \mathrm{O}_{5}$ were effected by the addition of different amounts of calcium lactate and acid sodium phosphate to the diet, and in the majority of cases were so arranged that during the earlier stages of the experiments there was a gradual increase in the daily intake of phosphorus, while that of calcium remained low ; in the final stage the calcium intake was at one step largely augmented, the phosphorus being maintained at its previous level. These alterations in the diet were made at intervals of five or six days, and during each period the serum phosphate was twice 
determined, usually on the third and fifth or sixth days. Throughout the experiments all the patients were confined to bed.

The method employed for estimation of the inorganic phosphorus of the serum was that of Tisdall $\left({ }^{15}\right)$; and due care was taken in every case to separate the serum from the blood as rapidly as possible.

Results.

In the later experiments minor changes were made in the amounts of calcium and phosphorus salts added to the diet, hence it has been necessary to divide the results into groups. Those obtained in the normal cases are summarised in Tables I.-IV., and graphed in Charts I.-V., those in the rachitic cases in Tables V. and VI., and Charts VI. and VII.

TABLE I.

Normal Children.

\begin{tabular}{|c|c|c|c|c|c|c|c|c|c|c|}
\hline \multirow{2}{*}{$\begin{array}{c}\text { Day of } \\
\text { Experi- } \\
\text { ment. }\end{array}$} & \multirow{2}{*}{\multicolumn{5}{|c|}{ Diet. }} & & \multicolumn{2}{|c|}{ Intake. } & \multicolumn{2}{|c|}{$\begin{array}{l}\text { P. in mg. per } 100 \\
\text { c.c. serum. }\end{array}$} \\
\hline & & & & & & & $\mathrm{CaO}$ & $\mathrm{P}_{2} \mathrm{O}_{\overline{5}}$ & Case 1. & Case 2. \\
\hline $1-4$ & Die & (A) & + (a. lact. 5 grm. & . & . & $\ldots$ & $1 \cdot 44$ & $1 \cdot 15$ & $4 \cdot 2$ & $4 \cdot 4$ \\
\hline $4-7$ & ", & , & . & . & . & . & $0 \cdot 16$ & $1 \cdot 15$ & $4 \cdot 1$ & $4 \cdot 2$ \\
\hline $7-9$ & , &, & . & . & . & $\ldots$ & $0 \cdot 16$ & $1 \cdot 15$ & $4 \cdot 0$ & $4 \cdot 2$ \\
\hline $9-12$ & , &, & $+\mathrm{NaH}_{2} \mathrm{PO}_{4} 3 \mathrm{grm}$. & . & . & . & $0 \cdot 16$ & 2.92 & $4 \cdot 4$ & $5 \cdot 4$ \\
\hline $12-14$ & , & , & $+\mathrm{NaH}_{2} \mathrm{PO}_{4} 3 \mathrm{grm}$. & . & . & . & $0 \cdot 16$ & $2 \cdot 92$ & $4 \cdot 3$ & $5 \cdot 2$ \\
\hline $14-17$ & , & , & $+\mathrm{NaH}_{2} \mathrm{PO}_{4} 6$ grm. & . & . & . & $0 \cdot 16$ & $4 \cdot 69$ & $4 \cdot 4$ & $5 \cdot 6$ \\
\hline $17-19$ & , & ," & $+\mathrm{NaH}_{2} \mathrm{PO}_{4} 6$ grm. & . & . & . & $0 \cdot 16$. & $4 \cdot 69$ & $5 \cdot 0$ & $5 \cdot 8$ \\
\hline $19-22$ & " & & $\begin{array}{c}+\mathrm{NaH}_{2} \mathrm{PO}_{4} 6 \text { grm. } \\
5 \text { grm. }\end{array}$ & $\begin{array}{l}\text { and } \\
\ldots\end{array}$ & $\begin{array}{l}\text { Ca. lact. } \\
\quad .\end{array}$ & & $1 \cdot 44$ & $4 \cdot 69$ & $5 \cdot 1$ & $5 \cdot 4$ \\
\hline $22-24$ & , & & $\begin{array}{c}+\mathrm{NaH}_{2} \mathrm{PO}_{4} 6 \text { grm. } \\
5 \text { grm. }\end{array}$ & $\begin{array}{l}\text { and } \\
\ldots\end{array}$ & $\begin{array}{c}\text { Ca. Lact. } \\
\quad . .\end{array}$ & & $1 \cdot 44$ & $4 \cdot 69$ & $5 \cdot 0$ & $5 \cdot 9$ \\
\hline $24-27$ & $"$ & & $\begin{array}{c}+\mathrm{NaH}_{2} \mathrm{PO}_{4} 6 \text { grm. } \\
12 \cdot 5 \text { grm. }\end{array}$ & $\begin{array}{c}\text { and } \\
\ldots\end{array}$ & $\begin{array}{l}\text { Ca. lact. } \\
\quad .\end{array}$ & .. & $3 \cdot 35$ & $4 \cdot 69$ & $4 \cdot 9$ & - \\
\hline $27-30$ & " & & $\begin{array}{c}+\mathrm{NaH}_{2} \mathrm{PO}_{4} 6 \mathrm{grm} . \\
\qquad 2.5 \mathrm{grm} .\end{array}$ & $\begin{array}{c}\text { and } \\
\ldots\end{array}$ & $\begin{array}{c}\text { Ca. lact. } \\
\text {.. }\end{array}$ & & $3 \cdot 35$ & $4 \cdot 69$ & $4 \cdot 7$ & - \\
\hline
\end{tabular}

CASEs 1 and 2. (Table I.) (Chart I.)

In both cases the serum phosphorus was unaffected by the initial reduction of calcium in the diet, but showed a definite rise in response to increase in the intake of phosphates. This was more marked in Case 2 , in which it amounted to $1.4 \mathrm{mg}$. per 100 c.c. Subsequent slight increase in the calcium intake was without effect on the serum phosphorus, and at this point the investigation in Case 2 was unavoidably cut short. In Case 1 a further increase in the calcium was followed by a slight but definite fall in the serum phosphorus, which, however, still remained well above the original level. . It is to be noted that the $\mathrm{CaO}: \mathrm{P}_{2} \mathrm{O}_{5}$ ratio at the beginning of this experiment was nearly twice as great as at the end. 
TABLE II.

Normal Children.

\begin{tabular}{|c|c|c|c|c|c|c|c|}
\hline \multirow{2}{*}{$\begin{array}{l}\text { Day of } \\
\text { Experi- } \\
\text { ment. }\end{array}$} & \multirow{2}{*}{\multicolumn{3}{|c|}{ Diet. }} & \multicolumn{2}{|c|}{ Intake. } & \multicolumn{2}{|c|}{$\begin{array}{l}\text { P. in mg. per } 100 \\
\text { c.c. serum. }\end{array}$} \\
\hline & & & & $\mathrm{CaO}$ & $\mathrm{P}_{2} \mathrm{O}_{5}$ & Case 3. & Case 4 . \\
\hline $1-4$ & & $\begin{array}{c}\text { (A) + Ca. lact. } 5 \text { grm. } \\
2 \text { grm. } \quad \cdots\end{array}$ & $\begin{array}{c}+\mathrm{NaH}_{2} \mathrm{PO}_{4} \\
\cdots \\
\cdots\end{array}$ & $1 \cdot 44$ & $2 \cdot 33$ & $4 \cdot 9$ & $5 \cdot 5$ \\
\hline $4-7$ & , & $"+\mathrm{NaH}_{2} \mathrm{PO}_{4} 2 \mathrm{grm}$. & $\cdots$ & $0 \cdot 16$ & $2 \cdot 33$ & $5 \cdot 8$ & $5 \cdot 8$ \\
\hline $7-9$ & $"$ & $" \quad+\mathrm{NaH}_{2} \mathrm{PO}_{4} 2$ grm. & $\cdots$ & $0 \cdot 16$ & $2 \cdot 33$ & $5 \cdot 6$ & $5 \cdot 7$ \\
\hline $\begin{array}{r}9-12 \\
12-14\end{array}$ & ", & $\begin{array}{l}" \quad+\mathrm{NaH}_{2} \mathrm{PO}_{4} 4 \mathrm{grm} . \\
" \quad+\mathrm{NaH}_{2} \mathrm{PO}_{4} 4 \mathrm{grm} .\end{array}$ & $\begin{array}{ll}\cdots & \ldots \\
\cdots & \cdots\end{array}$ & $\begin{array}{l}0 \cdot 16 \\
0 \cdot 16\end{array}$ & $\begin{array}{l}3 \cdot 51 \\
3 \cdot 51\end{array}$ & $\begin{array}{l}6 \cdot 0 \\
6 \cdot 1\end{array}$ & $\begin{array}{l}6 \cdot 1 \\
5 \cdot 8\end{array}$ \\
\hline $14-17$ & $"$ & $" \quad+\mathrm{NaH}_{2} \mathrm{PO}_{4} 6$ grm. & . & $0 \cdot 16$ & $4 \cdot 69$ & $6 \cdot 2$ & $6 \cdot 1$ \\
\hline $17-19$ & $"$ & $" \quad+\mathrm{NaH}_{2} \mathrm{PO}_{4} 6 \mathrm{grm}$ & . $\quad$. & $0 \cdot 16$ & $4 \cdot 69$ & $6 \cdot 3$ & $6 \cdot 1$ \\
\hline $19-22$ & $"$ & $=\underset{12 \cdot 5 \text { grm. }}{=+\mathrm{NaH}_{2} \mathrm{PO}_{4} 6 \text { grm. }}$ & $\begin{array}{l}+ \text { Ca. lact. } \\
\ldots \\
\cdots\end{array}$ & $3 \cdot 35$ & $4 \cdot 69$ & $6 \cdot 0$ & $5 \cdot 2$ \\
\hline $22-25$ & ", & 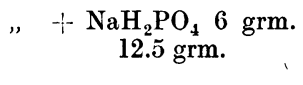 & $\begin{array}{l}+ \text { Ca. lact. } \\
\ldots \\
\ldots\end{array}$ & $3 \cdot 35$ & $4 \cdot 69$ & $5 \cdot 1$ & $5 \cdot 4$ \\
\hline $25-27$ & " & $=\underset{12 \cdot 5}{\text { grm. }}$ & $\begin{array}{l}\text { + Ca. lact. } \\
\ldots \quad \ldots\end{array}$ & $3 \cdot 35$ & $4 \cdot 69$ & - & $5 \cdot 4$ \\
\hline
\end{tabular}

CHART I.

CHART II.

CHART III.

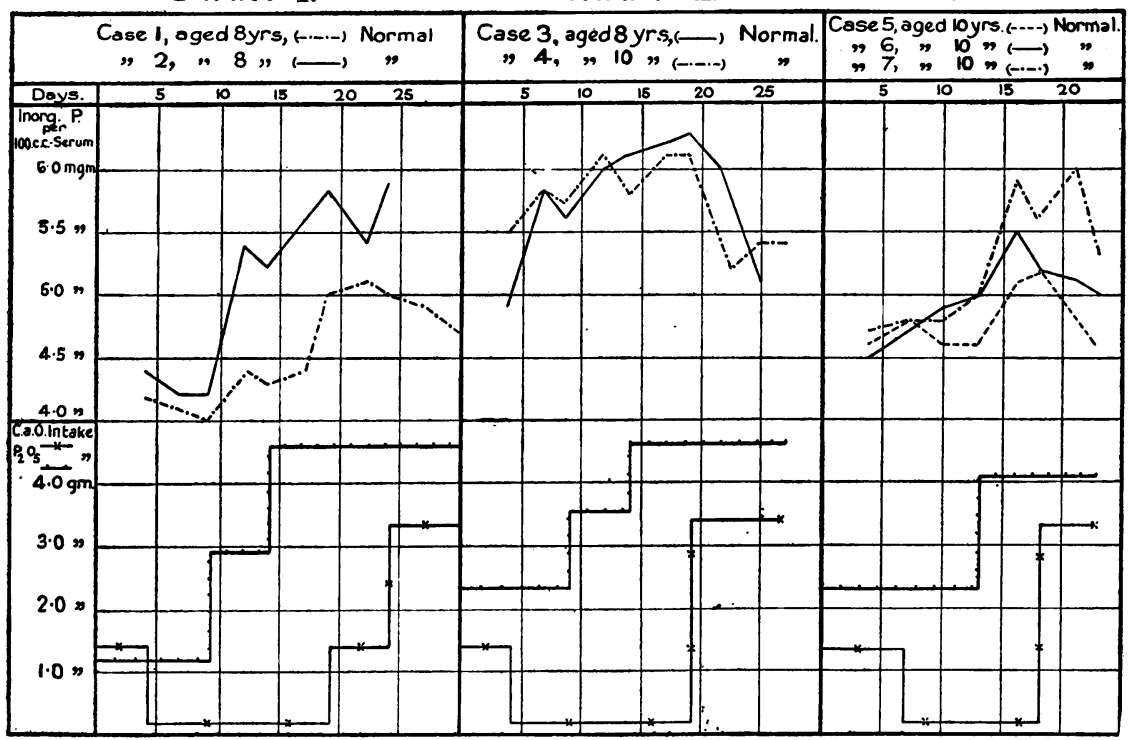

Showing Serum P. Curves in Feeding Experiments in Normal Children (Cases I-VII).

Cases 3 and 4. (Table II.) (Chart II.)

In this group the diet was adjusted so that there was no great discrepancy between the $\mathrm{CaO}: \mathrm{P}_{2} \mathrm{O}_{5}$ ratios at the beginning and at the end of the experiment, the figures being 0.6 and 0.7 respectively. 
Case 3 responded to an increasing phosphorus intake with a rise of $1.5 \mathrm{mg}$. P. per $100 \mathrm{c.c}$ serum ; later an increase in the calcium of the diet was followed by a marked drop in the serum phosphorus, which almost regained its initial level.

The corresponding changes in Case 4, though more erratic, were similar in general trend.

TABLE III.

Normal Children.

\begin{tabular}{|c|c|c|c|c|c|c|c|}
\hline \multirow{2}{*}{$\begin{array}{l}\text { Day of } \\
\text { Experi- } \\
\text { ment. }\end{array}$} & \multirow{2}{*}{\multicolumn{2}{|c|}{ Diet. }} & \multicolumn{2}{|c|}{ Intake. } & \multicolumn{3}{|c|}{$\begin{array}{l}\text { P. in mg. per } 100 \\
\text { c.c. serum. }\end{array}$} \\
\hline & & & $\mathrm{CaO}$. & $\mathrm{P}_{2} \mathrm{O}_{5}$. & Case 5. & Case 6. & Case 7. \\
\hline $1-4$ & & 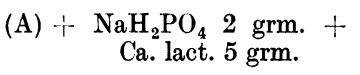 & $1 \cdot 44$ & $2 \cdot 33$ & $4 \cdot 6$ & $4 \cdot 5$ & $4 \cdot 7$ \\
\hline $4-7$ & & 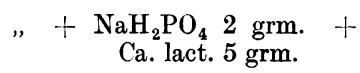 & $1 \cdot 44$ & $2 \cdot 33$ & $4 \cdot 8$ & $4 \cdot 7$ & $4 \cdot 8$ \\
\hline $7-10$ & , & $" \quad+\mathrm{NaH}_{2} \mathrm{PO}_{4} 2 \mathrm{grm}$. & $0 \cdot 16$ & $2 \cdot 33$ & $4 \cdot 6$ & $4 \cdot 9$ & $4 \cdot 8$ \\
\hline $10-13$ & , & $"+\mathrm{NaH}_{2} \mathrm{PO}_{4} 2$ grm. & $0 \cdot 16$ & $2 \cdot 33$ & $\cdot 4 \cdot 6$ & $5 \cdot 0$ & $5 \cdot 0$ \\
\hline $13-16$ & $"$ & $"+\mathrm{NaH}_{2} \mathrm{PO}_{4} 5$ grm. & $0 \cdot 16$ & $4 \cdot 1$ & $5 \cdot 1$ & $5 \cdot 5$ & $5 \cdot 9$ \\
\hline $16-18$ & " & $"+\mathrm{NaH}_{2} \mathrm{PO}_{4} 5$ grm. & $0 \cdot 16$ & $4 \cdot 1$ & $5 \cdot 2$ & $5 \cdot 2$ & $5 \cdot 6$ \\
\hline $18-21$ & , & $\begin{array}{c}"+\mathrm{NaH}_{2} \mathrm{PO}_{4} 5 \text { grm. }+ \\
\text { Ca. lact. } 12 \cdot 5 \text { grm. }\end{array}$ & $3 \cdot 35$ & $4 \cdot 1$ & $4 \cdot 8$ & $5 \cdot 1$ & $6 \cdot 0$ \\
\hline $21-23$ & & $\begin{array}{c}=+\underset{\text { Ca. lact. } 12 \cdot 5 \text { grm. }}{\mathrm{NaH}_{2} \mathrm{PO}_{4} 5} \text { grm. } \\
+\end{array}$ & $3 \cdot 35$ & $4 \cdot 1$ & $4 \cdot 6$ & $5 \cdot 0$ & $5 \cdot 3$ \\
\hline
\end{tabular}

Cases 5, 6 and 7. (Table III.) (Chart III.)

An effort was made still farther to increase the $\mathrm{CaO}: \mathrm{P}_{2} \mathrm{O}_{5}$ ratio in the final stage of the experiment. As it was impracticable to give more than $12.5 \mathrm{grm}$. of calcium lactate daily, this object was arrived at by reducing the amount of $\mathrm{NaH}_{2} \mathrm{PO}_{4}$ added to the diet.

All three cases exhibited a rise in serum phosphorus following increased intake of phosphates, although in Case 5 the increment was small. Again the addition to the diet of calcium in excess was attended by a fall in the serum phosphorus, though not to the original level.

TABLE IV.

Normal Child.

\begin{tabular}{|c|c|c|c|c|c|c|c|c|c|}
\hline \multirow{2}{*}{$\begin{array}{l}\text { Day of } \\
\text { Experi- } \\
\text { ment. }\end{array}$} & \multicolumn{6}{|c|}{ Diet. } & \multicolumn{2}{|c|}{ Intake. } & \multirow{2}{*}{$\frac{\text { Serum } P .}{\text { Case } 8 .}$} \\
\hline & & & & & & & $\mathrm{CaO}$. & $\mathrm{P}_{2} \mathrm{O}_{5}$. & \\
\hline $1-4$ & Milk & 825 c.c. & .. & .. & & . & $1 \cdot 4$ & $1 \cdot 8$ & $4 \cdot 1$ \\
\hline $4-7$ & ", & ", & .. & .. & & .. & $1 \cdot 4$ & $1 \cdot 8$ & $4 \cdot 2$ \\
\hline $7-10$ & " & , & $+\mathrm{NaH}_{2} \mathrm{P}$ & ${ }_{4} 4 \mathrm{grm}$. & & .. & 1.4 & $4 \cdot 17$ & 5.0 \\
\hline $10-13$ & $"$ & $"$ & , & $"$ & & .. & $1 \cdot 4$ & $4 \cdot 17$ & $4 \cdot 6$ \\
\hline $13-16$ & $"$ & $"$ & , & ," & & . & $1 \cdot 4$ & $4 \cdot 17$ & $4 \cdot 7$ \\
\hline $16-20$ & $"$ & " & $"$ & ", & $+c$ & ct. 10 grm. & $3 \cdot 9$ & $4 \cdot 17$ & $4 \cdot 0$ \\
\hline $20-22$ & $"$ & , & ", & , & , & $"$ & $3 \cdot 9$ & $4 \cdot 17$ & $4 \cdot 2$ \\
\hline
\end{tabular}




\section{Case 8. (Table IV.) (Chart IV.)}

The basic diet in this instance was whole milk, and the calcium-phosphorus intake was therefore high at the beginning, and greatly in excess at the end of the experiment. In the last 4 days there was some slight vomiting.

The rise in the serum phosphorus following high phosphorus feeding was definite but not very marked, amounting to $0.8 \mathrm{mg}$. per 100 c.c. During the last period, when the $\mathrm{CaO}: \mathrm{P}_{2} \mathrm{O}_{5}$ ratio was 0.9 , as compared with 07 at the outset, a diminution of $0.7 \mathrm{mg}$. per 100 c.c. occurred in the phosphorus of the serum.

\section{Case 9. (ChaRt V.)}

In this case the calcium-phosphorus intake remained constant throughout. During the first 5 days the serum phosphorus was determined daily, and for the remainder of the period estimations were made at intervals of 3 or 4 days. The total range was from $4 \cdot 9 \mathrm{mg}$. to $5 \cdot 3 \mathrm{mg}$. P. per 100 c.c., and for the most part the day to day fluctuations were negligible.

\section{TABLE V.}

Active Rickets.

\begin{tabular}{|c|c|c|c|c|c|c|c|c|}
\hline \multirow{2}{*}{$\begin{array}{l}\text { Day of } \\
\text { Experi- } \\
\text { ment. }\end{array}$} & \multirow{2}{*}{\multicolumn{4}{|c|}{ Diet. }} & \multicolumn{2}{|c|}{ Intake. } & \multicolumn{2}{|c|}{$\begin{array}{l}\text { P. in mg. per } 100 \\
\text { c.c. serum. }\end{array}$} \\
\hline & & & & & $\mathrm{CaO}$. & $\mathrm{P}_{2} \mathrm{O}_{5}$ & Case 10. & Case 11. \\
\hline $1-3$ & Milk 1050 & 0 c.c. $\quad \ldots$ & $\ldots$ & $\ldots$ & $1 \cdot 73$ & $2 \cdot 3$ & $3 \cdot 6$ & $3 \cdot 9$ \\
\hline $3-6$ & $\operatorname{Diet}(\mathrm{B})$ & $+\mathrm{NaH}_{2} \mathrm{PO}_{4} 1.6 \mathrm{grm}$ & $\cdots$ & $\cdots$ & $0 \cdot 78$ & $2 \cdot 03$ & $3 \cdot 7$ & $3 \cdot 8$ \\
\hline $6-9$ & , & $+\mathrm{NaH}_{2} \mathrm{PO}_{4} 1 \cdot 6 \mathrm{grm}$. & . & $\cdots$ & $0 \cdot 78$ & $2 \cdot 03$ & $3 \cdot 5$ & $3 \cdot 9$ \\
\hline $9-12$ & , & $+\mathrm{NaH}_{2} \mathrm{PO}_{4} 3.3 \mathrm{grm}$ & $\cdots$ & $\ldots$ & $0 \cdot 78$ & $3 \cdot 03$ & - & $3 \cdot 9$ \\
\hline $12-14$ & , & $+\mathrm{NaH}_{2} \mathrm{PO}_{4} 3 \cdot 3$ grm. & $\ldots$ & $\ldots$ & $0 \cdot 78$ & 3.03 & $4 \cdot 1$ & $4 \cdot 2$ \\
\hline $14-17$ & , & $+\mathrm{NaH}_{2} \mathrm{PO}_{4} 4 \cdot 2 \mathrm{grm}$. & $\ldots$ & $\ldots$ & $0 \cdot 78$ & $3 \cdot 56$ & $3 \cdot 4$ & $3 \cdot 9$ \\
\hline $17-19$ & " & $+\mathrm{NaH}_{2} \mathrm{PO}_{4} 5$ grm. & $\cdots$ & $\ldots$ & $0 \cdot 78$ & $4 \cdot 06$ & $3 \cdot 5$ & $4 \cdot 3$ \\
\hline $19-22$ & , & $+\mathrm{NaH}_{2} \mathrm{PO}_{4} 5 \mathrm{grm} .+$ & grm. & $\cdots$ & $1 \cdot 8$ & $4 \cdot 06$ & $3 \cdot 3$ & $3 \cdot 9$ \\
\hline $22-24$ & " & $+\mathrm{NaH}_{2} \mathrm{PO}_{4} 5$ grm. $+\underset{\text { lact }}{+}$ & grm. & $\cdots$ & $1 \cdot 8$ & $4 \cdot 06$ & 一 & $3 \cdot 7$ \\
\hline $24-27$ & $"$ & $+\mathrm{NaH}_{2} \mathrm{PO}_{4} 5 \mathrm{grm} .+$ & grm. & $\ldots$ & $2 \cdot 8$ & $4 \cdot 06$ & - & $3 \cdot 7$ \\
\hline $27-29$ & ," & $+\mathrm{NaH}_{2} \mathrm{PO}_{4} 5 \mathrm{grm} .+$ & grm. & $\cdots$ & $2 \cdot 8$ & $4 \cdot 06$ & - & $3 \cdot 5$ \\
\hline
\end{tabular}

Cases 10 and 11. (Table V.) (Chart VI.)

In Case 10 the behaviour of the serum phosphorus was somewhat erratic. Unfortunately the experiment had to be curtailed before the final increase in calcium had been made, but even the very moderate increase that was effected, was associated with a slight fall in the serum phosphorus. The changes in the latter that occurred in Case 11 appeared to be more definitely related to the diet. Thus, increased intake of phosphates was followed by a definite rise in the serum phosphorus, while subsequent increase in calcium apparently brought about a fall of $0.8 \mathrm{mg}$. per 100 c.c. It is noticeable that in both these cases the serum phosphorus was lower at the end of the experiment than it had been originally. 
CHART IV

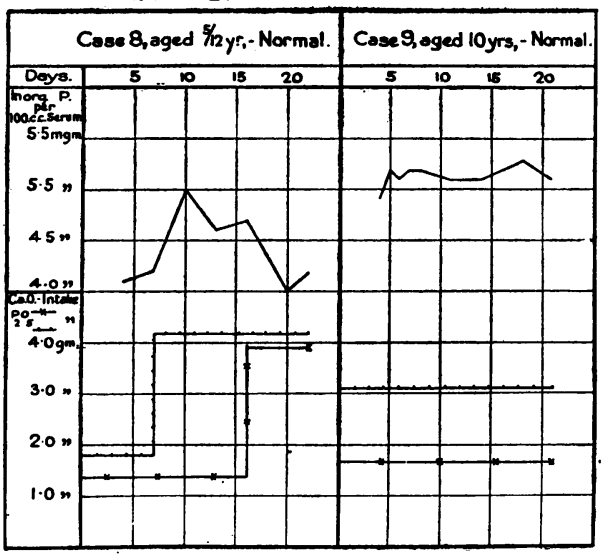

CHART. VI

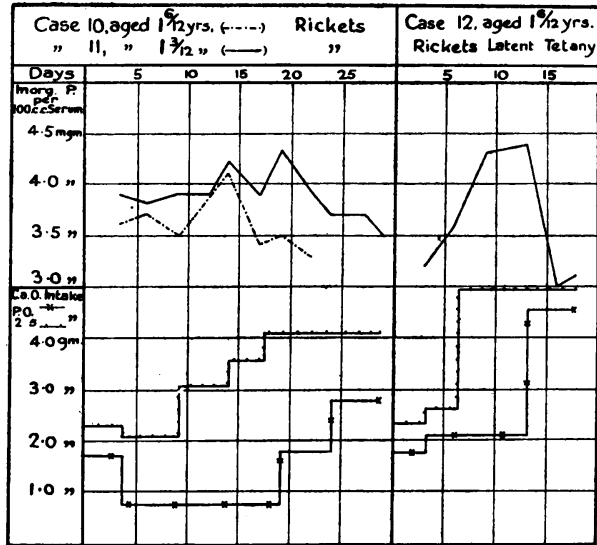

Showing Serum P. Curves in Feeding Experiments: $I V$ and $V$, Normal Children (Cases VIII and IX): VI and VII, Rachitic Children (Cases X-XII).

TABLE VI.

Active Rickets-Latent Tetany.

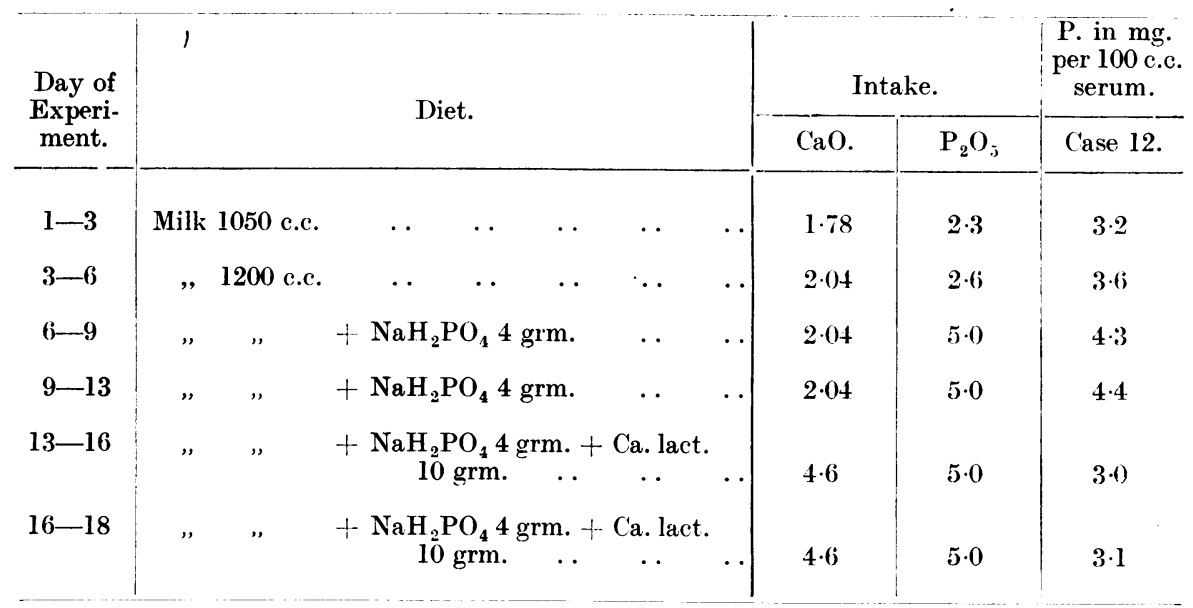

CASE 12. (Table VI.) (Chart VII.)

As in Case 8, the basic diet was whole milk, and the variations in the calcium-phosphorus intake were similar in both cases. The serum phosphorus (which, however, was already tending upwards) rose considerably when the phosphates in the diet were increased, but the most striking feature of the case was the pronounced fall in the serum phosphorus ( $1 \cdot 3 \mathrm{mg}$. per $100 \mathrm{c.c}$.) which took place when the calcium intake was substantially augmented.

A disturbing factor in this instance was the appearance, on the 5th day, of Chvostek's sign. From the 6th day onwards, the sign could not be elicited, and at no time was there any other evidence of latent tetany, facts which will be commented upon later.

\section{Discussion.}

In interpreting these results it is necessary to bear in mind certain facts with regard to the phosphorus content of the blood and the variations to which, under normal physiological conditions, it is subject. 
In contrast to calcium, which varies only within narrow limits, the blood phosphorus fluctuates rather widely. Howland and Kramer ( ${ }^{2}$ ) who investigated this factor in a number of healthy children, found the average value to be $5.4 \mathrm{mg}$. inorganic phosphorus per 100 c.c. serum, with $7 \cdot 1 \mathrm{mg}$. and $4 \mathrm{mg}$. per 100 c.c. as the extreme values. The much lower level of phosphate in the serum of adults (averaging, according to Howland and Kramer, $2 \cdot 1 \mathrm{mg}$. per 100 c.c.) is attained not by any slow gradations, but by an abrupt fall about the 20th year, which marks the end of the period of active bone growth ${ }^{(16)}$. The bearing of this fact upon the present investigation is that comparison of figures obtained in the normal and rachitic groups would appear valid, though the average age of the former considerably exceeded that of the latter.

It is stated by Greenwald ( ${ }^{17}$ ) that the inorganic phosphorus of the serum is increased after food. Experimenting on adults, he found a rise averaging $2.5 \mathrm{mg}$. per 100 c.c. in the acid-soluble phosphorus of the serum two and a half hours after a meal containing meat, and concluded that "from the large variations found, the content of this form of phosphorus in the serum may be largely dependent on the character of the food and the stage of digestion."

Again, Havard and Reay ${ }^{(18)}$ have recently adduced-evidence to prove that muscular activity has an effect upon the phosphorus content of the serum. They found that in adults vigorous exercise produced a rise averaging 10 per cent., followed by a fall of about twice that extent, results which they attributed to changes in the lactacidogen content of the muscles.

Lastly, since the phosphates of the serum are generally held to constitute one of the factors by which the acid-base equilibrium is regulated, their amount might be expected to vary on this count alone. In this connection it is, however, interesting to note that several observers including Denis and Minot (19) and Jones and Nye ${ }^{(20}$ ) were unable to establish any relationship between the alkali reserve and the phosphate content of the blood.

In any event it is clear that the term "normal serum phosphorus" is an elastic one, the figure varying not only from one individual to another, but in the same individual from time to time. The questions therefore ariseHow far may the variations recorded in the present series of cases be attributed to changes in the calcium-phosphorus content of the diet, and how far are they the result of other factors? It was to decide this point that the experiment on Case 9 was carried out, the results of which are recorded in Chart V. These appear to warrant the conclusion that under controlled conditions of rest and uniformity of diet, the inorganic phosphorus of blood sampled at a regular hour, varies comparatively little from day to day in the normal child. Considering then at present only the normal cases, it may reasonably be claimed that the larger variations recorded are the direct result of changes in the calcium-phosphorus content of the diet. This assumption is supported by the regular trend of the figures themselves, which show that an increased intake of phosphorus consistently gave rise to an increase in the inorganic phosphate of the serum, and that a decline in the level of the latter resulted in every case from the addition of calcium in excess to the diet. 
The serum phosphorus does not appear to be influenced with equal readiness in all cases. The fall consequent upon an increased intake of calcium, though definite in every instance, was most marked in Case 3, where it amounted to $1.2 \mathrm{mg}$. per 100 c.c. serum. In the same child, a rise of $1 \mathrm{mg}$. per 100 c.c. followed the initial reduction in the calcium intake, though no increase had been made in that of phosphorus. In no case was the serum phosphorus raised definitely above, or depressed below, normal limits.

Experiments upon animals have been recorded by Kramer and Howland ( ${ }^{21}$ ) and by Park, Guy and Powers (22) in which was studied the influence of changes in the $\mathrm{CaO}: \mathrm{P}_{2} \mathrm{O}_{3}$ ratio of the food on the serum phosphate, but the fact that gross departures from the normal were made in the diet, so that in most cases the animals developed rickets, invalidates comparison with the results of the present investigation. Reference may, however, be made to certain experiments on heifers described by Meigs, Blatherwick and Cary (23) from which it appeared that the addition of a calcium salt (in this case $\mathrm{CaCl}_{2}$ ) to the standard ration resulted in a reduction in the inorganic phosphorus of the plasma. This is in agreement with the results obtained by the writer in the case of normal children, which show that the amount of calcium ingested undoubtedly influences the phosphorus content of the serum.

Certain differences are to be observed between the curves obtained in the normal and in the rachitic groups. In two cases of rickets (Nos. 10 and 11) and particularly in the former, the rise induced in the serum phosphorus during the earlier stage of the experiments was somewhat spasmodic and ill-sustained. The influence of an increased intake of calcium in depressing the serum phosphorus level was, however, very definite, and it is to be noted that in both instances this level was lower at the end of the experiment than it had been at the beginning. Unfortunately no information is available as to the possible extent of the ordinary daily fluctuations in the serum phosphorus in rickets, since it was not found possible, during the period of study, to investigate this point separately in a rachitic infant as had been done in a normal child (Case 9).

Case 12 must be considered separately, as on the third day the experiment was unexpectedly complicated by the development of the facial phenomenon. No other signs of latent tetany could be elicited, and on the fifth and subsequent days, the sign was negative, though a further rise in the serum phosphorus followed the addition of $\mathrm{NaH}_{2} \mathrm{PO}_{4}$ to the diet. If the case be considered one of latent tetany, the doubt arises whether the striking drop in the serum phosphorus consequent upon the increase in the calcium intake may not have been simply the result of the therapeutic influence of calcium lactate, causing a reversion from the blood picture of tetany to that of uncomplicated rickets. Two considerations seem to negative this possibility. In the first place, there had been no evidence of tetany for several days before the calcium lactate was given; secondly, Anderson and Graham ( ${ }^{24}$ ) in a study of the rtiology of tetany made the observation that there was no relation between the phos phorus content of the serum and the appearance or disappearance of the tetany. 
In this case, therefore, as in the others, the most probable explanation of the effect of a calcium-rich diet upon the serum phosphorus is to be found in the well-recognised fact that an excess of lime in the intestine interferes with the absorption of phosphates by precipitating the latter in insoluble form. Comparison between Cases 7 (normal) and 12 (rachitic) which received practically the same diet, shows that the influence of calcium upon the serumphosphorus level was much more marked in the latter than in the former, a difference which can best be accounted for by the presumption that in the rachitic child, owing to defective absorption of calcium, there was a relative as well as an absolute excess of this substance in the gut.

\section{PART II.-Study of Phosphorus Absorption.}

In the work that remains to be described, the absorption of phosphorus in health and in rickets was investigated by a method which promised to afford direct information on the subject. It has been shown by Klercker and Odin $\left(^{(5)}\right.$ in a study of the genesis of so-called " phosphate tetany," that the introduction by mouth of a soluble phosphate results in a rise in the inorganic phosphorus of the serum. If in rickets there exists any intrinsic defect in the mechanism of phosphorus absorption, one would expect the response of the serum phosphorus to such a dose to be feeble or delayed, as contrasted with that in health.

It was accordingly decided to compare the changes in the phosphorus content of the serum in normal and rachitic children, following the ingestion of $\mathrm{NaH}_{2} \mathrm{PO}_{4}$.

\section{Method.}

In order to obtain a tentative idea of the general form of curve to be expected, a preliminary experiment was carried out upon the writer. Four hours after a meal, blood with withdrawn and 6 grm. $\mathrm{NaH}_{2} \mathrm{PO}_{4}$ dissolved in 120 c.c. water was then taken; afterwards blood was collected half-hourly for two hours. The inorganic phosphorus per 100 c.c. serum in the various samples was found to be as follows :-(1) $3.8 \mathrm{mg}$.; (2) $5.4 \mathrm{mg}$. ; (3) $5.5 \mathrm{mg}$.; (4) $6 \cdot 2 \mathrm{mg}$. ; (5) $6 \cdot 1 \mathrm{mg}$. From the information thus obtained, it was decided to determine the serum phosphorus concentration in all cases immediately before, and at intervals of one, two and four hours after the ingestion of $\mathrm{NaH}_{2} \mathrm{PO}_{4}$. In preference to regulating the dosage by the body.-weight of the patient, the same amount ( 4 grm. dissolved in 60 c.c. water,) was given in every case. An interval of at least 3 hours was allowed to elapse between the last meal and the beginning of the experiment, and fasting was continued till the last sample of blood had been withdrawn. In all, eleven cases were thus tested, of whom five were normal, four suffered from florid rickets, and two from rickets in the healing stage. As in the earlier experiments the normal controls were convalescent children who had been admitted to hospital some time previously; two cases with rheumatic carditis, two with bronchitis, and one with ileo-colitis. In the cases of rickets the diagnosis was invariably verified by X-ray examination. 
Results.

The results obtained in the three groups are collected in Tables VII-IX, and in Charts VIII-X they are presented in graphic form.

TABLE VII.

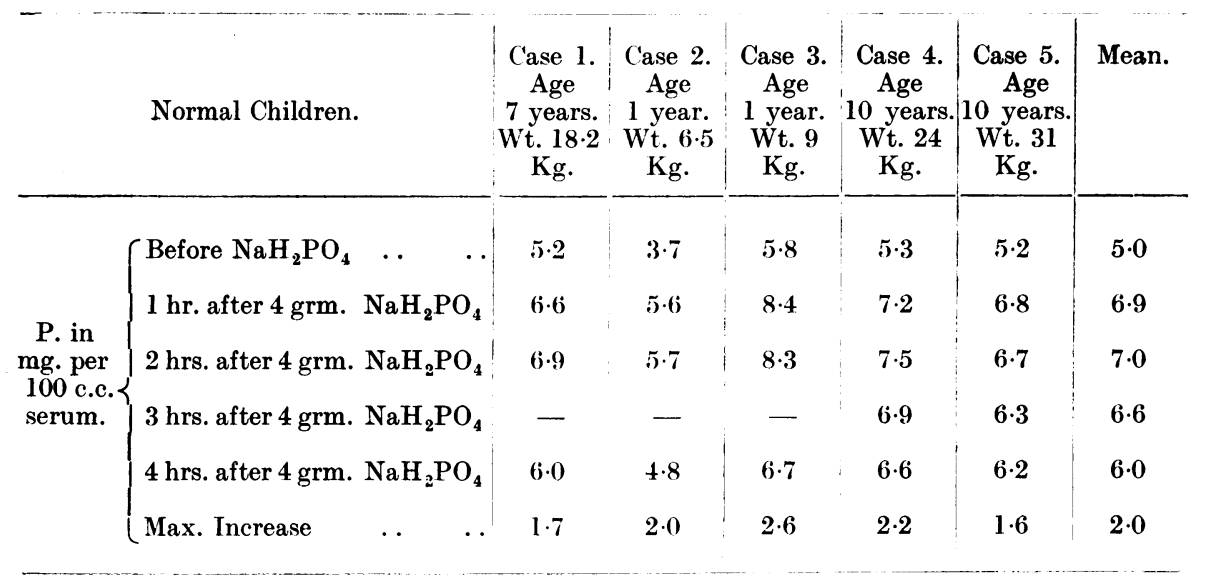

TABLE VIII.

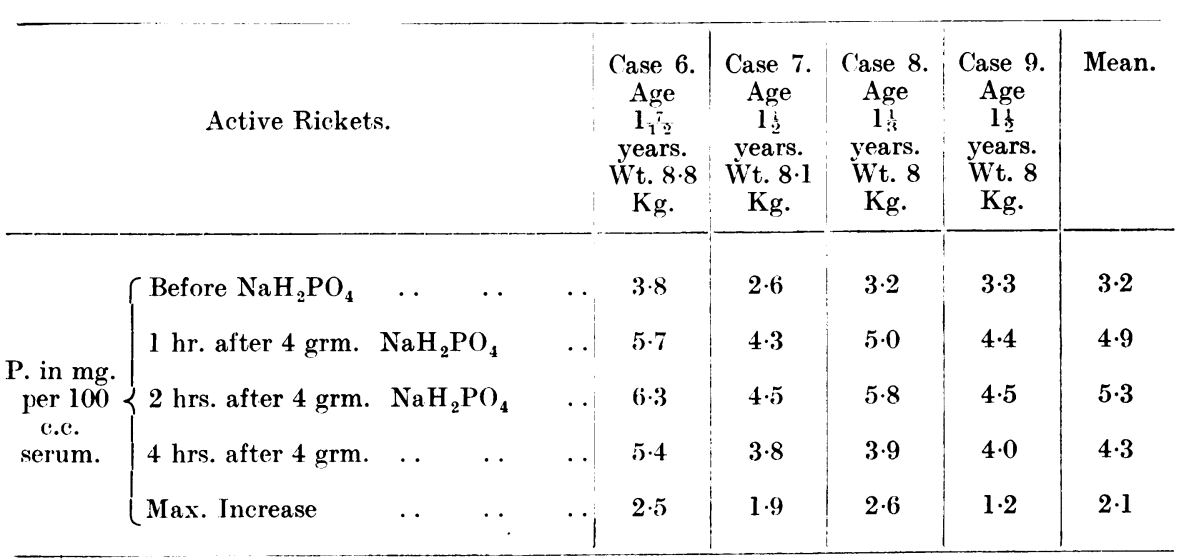

TABLE IX.

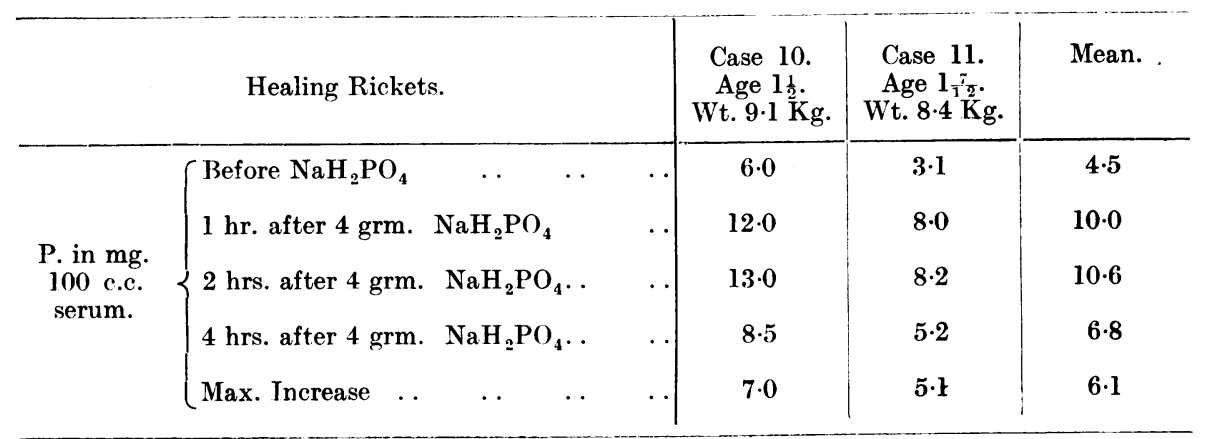




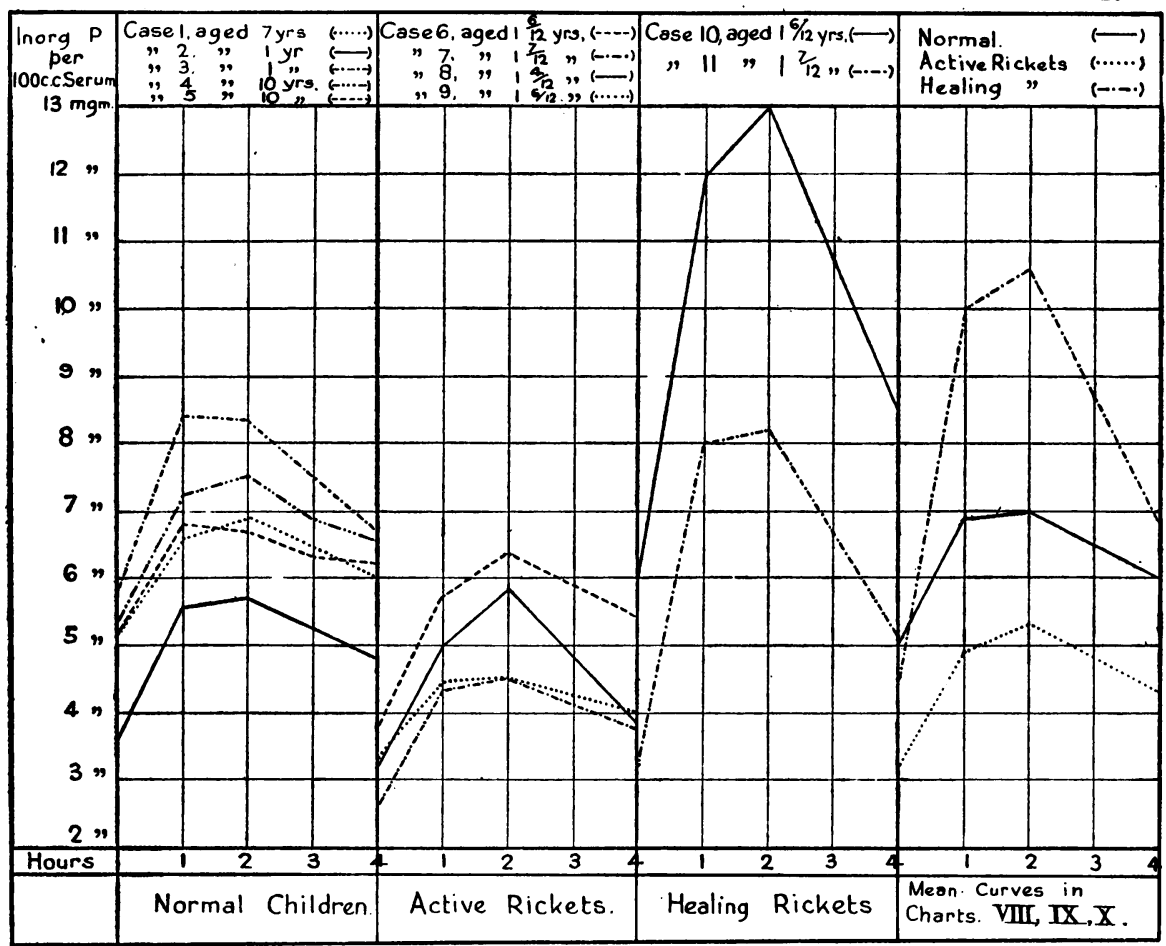

Showing Serum P. Curve after Administration per os of 4 grm. $\mathrm{NaH}_{2} \mathrm{PO}_{4}$ (Cases I-XI).

From Chart VIII it will be observed that the test yielded in every case a curve of well defined form, with a steep rise during the first hour and a gradual decline during the third and fourth hours. The average increase recorded was $2 \mathrm{mg}$. P. per 100 c.c., or 40 per cent. Case 2 calls for special comment on account of the unusually low initial level of the serum phosphate. This child presented no clinical signs of rickets but the result of serum analysis suggested that an X-ray examination of the wrist should be made. This showed, however, a completely normal condition of the bones. The existence of a subnormal phosphorus content of the blood in the absence of rickets has previously been recorded. Anderson $\left({ }^{3}\right)$ who determined the blood phosphorus in a large series of normal and rachitic children, found a low value in a number of cases which failed to develop rickets during a period of observation; in no case did a low value indicate the presence of rickets before other signs of the disease had been recognised. On these grounds it was considered justifiable to include Case 2 in the normal series.

If the curves in the normal cases are now compared with those obtained in active rickets, it will be seen that no significant difference exists between them. The general form of the curves in rickets is the same, the peak occurs at the end of two hours, and the average increase is $2 \mathrm{mg}$. P. per 100 c.c. serum. In only one instance, namely in Case 9, was the rise in the serum phosphorus $(1.2 \mathrm{mg}$. per 100 c.c.) less than in any of the normal cases. Against this may 
be set the fact that in Case 8, which presented clinical and radiographic signs of the most severe rickets, an increase of $2.5 \mathrm{mg}$. P. per 100 c.c. serum was induced, which compares very favourably with the average of $2 \mathrm{mg}$. per 100 c.c. in the normal group. Briefly, it may be said that in these cases of rickets the serum-phosphorus curve, except that it was transposed to a lower level, differed very little from that of healthy children.

Strikingly different results were yielded by the cases of healing rickets. One of these (Case 10) had been under treatment in hospital for some time, and showed every sign, clinical and radiographic, of rapid healing; the other (Case 11), showed a mild degree of rickets, and here also, X-ray examination showed that recovery was taking place. In both cases administration of $4 \mathrm{grm}$. of $\mathrm{NaH}_{2} \mathrm{PO}_{4}$ produced within an hour an enormous increment in the serum phosphorus, which in another hour had still further slightly increased. Thereafter, a sharp decline in the curve showed that the excess was being rapidly removed from the blood. . Of the two cases, No. 10, in which healing was further advanced, exhibited the greater rise, amounting to $7 \mathrm{mg}$. per 100 c.c. serum.

In Chart XI the mean curves in the three groups have been assembled for easy comparison, and the fact that by far the greatest rise was found in healing rickets is clearly brought out.

In the foregoing the validity of comparing results in children of widely differing weights may be questioned, since all received the same dose of $\mathrm{NaH}_{2} \mathrm{PO}_{4}$, but it should be noted that in the normal children there was no apparent relation between the body-weight and the extent of the increase in the serum phosphorus, as reference to Table VII will show. Thus in Case 4, with a weight of $24 \mathrm{~kg}$. there was recorded a rise of $2.2 \mathrm{mg}$. per 100 c.c., while in Case 2 weighing only $6.5 \mathrm{~kg}$. the corresponding figure was $2 \mathrm{mg}$. per 100 c.c. It is probable that in tests of this kind with soluble phosphates as in those with glucose (26), regulation of dosage by weight is of doubtful importance, since increase beyond a certain point in the amount ingested does not lead to a proportionate increase of the substance concerned in the blood.

Reference has been made to the fact that the children on whom these experiments were carried out had in every case fasted for at least 3 hours previously. This condition was observed in order that the absorption of the phosphorus itself might be tested, influenced as little as possible by the presence of any unabsorbed calcium in the stomach or upper part of the intestine.

As has been pointed out elsewhere, conclusions regarding internal metabolism which are based upon the results of analysis of the peripheral blood must be accepted with a certain degree of reserve, influenced as they necessarily are by multiple and often incalculable factors. Thus in the experiments described, the changes in the concentration of phosphorus in the serum depended not only upon the rate of absorption from the gut but also upon the rapidity with which the excess phosphate was removed from the blood by the tissues, and in particular by the kidneys ; but in the absence of evidence of any abnormality in the rate of excretion of phosphates, it is perhaps not unreasonable 
to regard the extent of the increase in the serum phosphorus following the ingestion of $\mathrm{NaH}_{2} \mathrm{PO}_{4}$, as an approximate measure of the absorption of that substance. If this be conceded, the foregoing experiments may be said to show (1) that in active rickets there is not necessarily any defect in the absorption of phosphorus, since in four cases studied the latter was found to be, on the average, equal to that in healthy children; (2) that in healing rickets the absorption of phosphorus may be three times as great as in health.

The latter observation is in accordance with the results of metabolism experiments recorded by Schabad ( $\left.{ }^{11}\right)$, and other observers $\left({ }^{8 a}\right)$ which show that the healing stage of rickets is characterized by an abnormally high balance of calcium and phosphorus, sometimes 60 per cent. to 80 per cent. of the quantity ingested being retained, or roughly twice the normal amount.

\section{SUMmaRY.}

In a study of the inorganic phosphorus of the serum, and the manner of its response to variations in the caleium-phosphorus intake, in eight normal and three rachitic children, the following observations were made.

A diet poor in calcium, and rich in phosphorus gave rise to an increase, though not beyond normal limits, in the phosphorus content of the serum.

Subsequent addition of calcium in excess to the diet induced a fall in the serum phosphorus, an effect which, while definite in every case, was more marked in the rachitic than in the normal children.

It was thus shown that in the cases in question the serum phosphorus was undoubtedly influenced by the amount of the calcium intake, excess of the latter being equivalent in effect to a diminished supply of phosphorus. The fact that the effect of calcium excess was greater in the rachitic children may be explained in the light of the hypothesis that in rickets, owing to defective absorption of calcium, the normal deterrent action of this element on phosphorus absorption is intensified.

The phosphorus absorptive power, as indicated by the rise in the inorganic phosphorus of the serum following the ingestion of 4 grm. of $\mathrm{NaH}_{2} \mathrm{PO}$, was separately investigated in 11 children of whom 5 were normal, 4 suffered from active rickets and 2 showed healing rickets.

It was found that in the cases of active rickets the average absorption was the same as in the healthy children, while in those of healing rickets it was abnormally high.

From a few examples, however apparently convincing, it is impossible to gather any general conclusion, but interest attaches to the foregoing results in that they are in keeping with the hypothesis of defective calcium absorption in rickets, while with the view that phosphorus metabolism is primarily at fault, they are directly at variance.

The work described in the preceding pages was carried out in the Royal Hospital for Sick Children, Glasgow, and was undertaken at the suggestion of Professor Leonard Findlay, for whose encouragement and valuable help the writer is deeply grateful. 


\section{REFERENCES.}

1. Iversen, P., and Lenstrup, E., Forhand. red. Forste. Nordiske Kongres. f. Paediat, 1920. (quoted by Howland and Kramer (2)).

2. Howland, J., and Kramer, B., Amer. J. Dis. Child., Chic., 1921, XXII, 105.

3. Anderson, G. H., Brit. J. Child. Dis., Lond., 1924, XXI, 33 and 107.

4. Howland, J., Medicine, Baltimore, 1923, II, 349.

5. Hess, A. F., and Gutman, M. B., J. Amer. Med. Assoc., Chic., 1922, LXXVIII, 29.

6. Hess, A. F., Unger, L. T., and Papperheimer, A. M., J. Biol. Chem., N.Y., 1922, L., 77.

7. Findlay, L., J. Amer. Med. Ass., Chic., 1924, LXXXIII, 1473.

8. Telfer, S. V., Quart. J. Med. Oxf., 1922-23, XVI, 45 and 63 ; ibid., 1923-24, XVII, 245.

8a. Quart. Jour. Med., Oxf., 1926, XX, 7.

9. Ahlquist, E., Skandin. Arch. f. Physiol., 1916, XXXIV, 1. (Quoted by Findlay, L. (7)).

10. Hoobler, B. R., Amer. J. Dis. Child., Chic., 1911, II, 107.

11. Schabad, J. A., Ztsch. f. klin. Med., Berlin, 1908-9. LXVII, 454 ; Ibid., 1909, LXVIII, 94 ; Ibid., 1910, LXIX, 435. Arch. f. Kinderh., Stuttgart, 1909, LII, 47 and 68 ; Ibid., 1910, LIII, 380. Jahrb. f. Kinderh., Berlin, 1910, LXXII, 1.

12. Orr, W. J., Holt, L. E., Wilkins, L., and Boone, F. H. ; Amer. J. Dis. Child., Chic., 1923, XXVI, 362.

13. Wills, L., Sanderson, P., and Paterson, D., Arch. Dis. Childhood, Lond., 1926, I, 245.

14. Sherman, H. C., Chemistry of Food and Nutrition, N.Y., Macmillan, 1911.

15. Tisdall, F. F., J. Biol. Chem., N.Y., 1922, L., 329.

16. Tisdall, F. F., and Harris, R. I., J. Amer. Med. Ass., Chic., 1922, LXXIX, 884.

17. Greenwald, I., J. Biol. Chem., N.Y., 1915, XXI, 29.

18. Havard, R. E., and Reay, G. A., J. Physiol., Camb., 1926, LXI, 35.

19. Denis, W., and Minot, A. S., Arch. Int. Med., Chic., 1920, XXVI, 99.

20. Jones, M. A., and Nye, L. N., J. Biol. Chem., N.Y., 1921, XLVII, 321.

21. Kramer, B., and Howland, J., Johns. Hopk. Hosp. Bull., Baltimore, 1922, XXXIII, 313.

22. Park, E. A., Guy, R. A., and Powers, G. F., Amer. J. Dis. Child., Chic., XXVI, 103.

23. Meigs, E. B., Blatherwick, N. R., and Cary, C. A., J. Biol. Chem., N.Y., 1919, XXXVII, 1.

24. Anderson, G. H., and Graham, S., Quart. J. Med., Oxf., 1924, XVIII, 62.

25. Klercker, K., and Odin, M., Acta Pad. Uppsala, 1925, V, 79.

26. McLean, H., and De Wesselow, O. L. V., Quart. J. Med., Oxf., 1920-21, XIV, 103. 